\title{
Analisis Motivasi Dan Pelatihan Kerja Terhadap Kinerja Pegawai PPL Pada Dinas Pertanian Kabupaten Kediri
}

\author{
Jaya Naviga Armandanto, Edy Swasono \\ Program Magister Manajemen, Program Pascasarjana, Universitas Islam Kadiri \\ Email : jayanaviga4@gmail.com
}

\begin{abstract}
This study aims to determine the effect of motivation and job training on the performance of PPL employees at the Kediri district agriculture office. The population of PPL employees at the Kediri Regency Agricultural Office is 149 people consisting of 84 PNS employees and 65 PPK. The sampling technique in this study used the Random Sampling method. The analysis technique used is quantitative analysis technique with multiple linear regression method. The results showed that motivation and job training had a simultaneous effect on the performance of PPL employees; motivation does not affect the performance of PPL employees; Job training affects the performance of PPL employees.

Keyword: Motivation, Job Training, Performance
\end{abstract}

\begin{abstract}
Abstrak
Penelitian ini bertujuan untuk mengetahui pengaruh motivasi dan pelatihan kerja terhadap kinerja pegawai PPL pada dinas pertanian kabupaten Kediri. Populasi pegawai PPL pada dinas pertanian kabupaten kediri adalah 149 orang yang terdiri dari 84 pegawai PNS dan 65 PPPK. Teknik pengambilan sampel pada penelitian ini menggunakan metode Random Sampling. Teknik analisis yang digunakan adalah teknik analisis kuantitatif dengan metode regresi linear berganda. Hasil penelitian menunjukkan bahwa motivasi dan pelatihan kerja berpengaruh secara simultan terhadap kinerja pegawai PPL; motivasi tidak berpengaruh terhadap kinerja pegawai PPL; pelatihan kerja berpengaruh terhadap kinerja pegawai PPL.

Kata Kunci : Motivasi, Pelatihan Kerja, Kinerja
\end{abstract}

\section{Latar Belakang Teoritis}

Pada perkembangan globalisasi ini banyak instansi pemerintahan yang dituntut untuk dapat memaksimalkan kinerja pegawai. Hal ini berarti bahwa sebuah instansi harus mampu menganalisis faktorfaktor yang dapat mempengaruhi kinerja pegawai. Dalam mengatasi hal tersebut sumber daya manusia (SDM) adalah paling utama yang harus diperhatikan perkembangannya karena dengan adanya SDM yang baik dan professional akan sangat membantu dalam memaksimalkan kinerja dalam suatu instansi. Dengan adanya SDM yang baik maka kinerja yang dihasilkan akan mempengaruhi kemajuan instansi tersebut begitu juga sebaliknya jika kinerja suatu instansi tidak baik maka akan menghambat kemajuan instansi. Menurut Suwatno (2011: 196) "kinerja merupakan performance atau unjuk kerja. Kinerja dapat pula diartikan sebagai prestasi kerja atau pelaksanaan kerja atau hasil unjuk kerja". Faktor-faktor yang mempengaruhi kinerja seseorang menurut
Robert L. Mathis dan John Jackson (2001: 82) yaitu kemampuan pegawai, motivasi, dukungan atau dorongan yang diterima, keberadaan pekerjaan yang dilakukan dan hubungan dengan organisasi atau instansi. Kinerja pegawai PPL pada Dinas Pertanian Kabupaten Kediri, masih kurang maksimal. Terdapat beberapa pegawai yang kurang profesional dan disiplin misalnya saat jam istirahat banyak pegawai yang mengulur waktu dan istirahatnya terlambat kembali pada tugas yang seharusnya dilaksanakan kurang maksimalnya kinerja yang dihasilkan oleh pegawai PPL pada Dinas Pertanian Kabupaten Kediri karena kurangnya motivasi kerja bagi pegawai.

Pengertian motivasi kerja menurut Suwatno (2011: 171) adalah motivasi berasal dari kata latin movere yang berarti dorongan, daya penggerak atau kekuatan yang menyebabkan suatu tindakan atau perbuatan. Kata movere, dalam bahasa inggris, sering disepadankan dengan motivation yang berarti pemberian motif, penimbulan motif, atau hal 
yang menimbulkan dorongan atau keadaan yang menimbulkan dorongan. Secara harfiah motivasi berarti pemberiaan motif. Seseorang melakukan suatu tindakan pada umumnya mempunyai suatu motif. Seseorang melakukan sesuatu dengan sengaja, tentu ada suatu maksud atau tujuan yang mendorongnya melakukan suatu tindakan. Motif dasar dari seseorang tersebut adalah adanya kebutuhan orang tersebut akan kebanggaan dan kehormatan serta, mungkin limpahan materi. Motivasi yang ada pada diri seseorang merupakan pendorong yang akan mewujudkan suatu perilaku guna mencapai tujuan kepuasan dirinya. Orang mau bekerja untuk memenuhi kebutuhan, baik kebutuhan yang disadari (conscious needs) maupun kebutuhan atau keinginan yang tidak disadari (unconscious needs); demikian juga orang mau bekerja untuk mendapatkan kebutuhan fisik dan mental. Dengan adanya motivasi yang baik dan tepat bagi pegawai akan sangat berguna untuk membangun kesadaran akan pentingnya kerja yang optimal, disiplin dan professional. Jika dilihat dari segi motivasi eksternal yang pegawai dapatkan, mereka kurang mendapatkan motivasi yang baik dari atasan ataupun partner kerjanya. Kurangnya motivasi tersebut menjadikan kurangnya kesadaran akan tanggung jawab pekerjaan pegawai tersebut. Untuk mengatasi hal tersebut perlu dilakukan pemberian motivasi kepada pegawai sehingga akan lebih termotivasi untuk dapat bekerja lebih disiplin dan bekerja lebih professional. Dengan adanya motivasi yang baik dan tepat yang ditujukan kepada pegawai akan sangat membantu dalam perkembangan kinerja pegawai itu sendiri dan tentunya dampak yang baik untuk Dinas Pertanian Kabupaten Kediri sehingga akan lebih maju dan unggul. Namun tidak hanya dengan motivasi yang baik saja yang mempengaruhi kinerja pegawai, pelatihan-pelatihan yang dilaksanakan oleh Dinas Pertanian Kabupaten Kediri diduga juga akan mempengaruhi kinerja pegawai. Dengan adanya pelatihan yang tepat dapat menjadikan pegawai bekerja dengan benar dan sesuai dengan bidangnya.

Pengertian tentang pelatihan itu sendiri menurut Gary Dessler dalam Suwatno (2011:118), pelatihan merupakan proses mengajarkan pegawai baru atau yang ada sekarang, keterampilan dasar yang mereka butuhkan untuk menjalankan pekerjaan mereka, sedangkan menurut Andrew dalam Suwatno (2011:117), pelatihan merupakan proses jangka pendek yang mempergunakan prosedur sistematis dan terorganisasi di mana pegawai non manajerial mempelajari pengetahuan dan keterampilan teknis dalam tujuan terbatas. Menurut Wayne dalam Suwatno (2011:117), pelatihan terdiri dari program-program yang disusun terencana untuk memperbaiki kinerja di level individual, kelompok dan organisasi, memperbaiki kinerja yang dapat diukur perubahannya melalui pengetahuan, keterampilan, sikap dan perilaku social dari pegawai itu. Pelatihan bagi pegawai bertujuan untuk memberikan pengetahuan dan keterampilan yang sesuai dengan bidang yang dikerjakan oleh pegawai, sehingga pegawai akan tepat sasaran sesuai dengan yang dikerjakannya dan jika pegawai mempunyai keahlian yang sesuai dengan bidangnya maka pekerjaan akan selesai tepat waktu. Pemberian pelatihan kerja juga harus sesuai dengan kebutuhan pegawai sehingga tidak akan mengorbankan banyak waktu dan biaya yang dikeluarkan. Pelatihan yang tepat ini akan memberikan kemampuan yang tepat pula bagi pegawai dan tentunya untuk Dinas Pertanian Kebupaten Kediri. Namun pada Dinas Pertanian Kabupaten Kediri kurang mendapatkan pelatihan yang cukup dalam pengembangan keterampilan ataupun inovasi. Kurangnya pelatihan kerja yang sangat bermanfaat pada perkembangan kemampuan pegawai untuk dapat berinovasi dalam bidang pelayanan Dinas Pertanian Kabupaten Kediri yang akan berdampak pada kemajuan kinerja. Dengan adanya inovasi dalam pelayanan tersebut akan meningkatkan kinerja pegawai sehingga keuntungan juga akan dirasakan masyarakat Kabupaten Kediri.

Oleh sebab itu penelitian ini dilakukan untuk meneliti lebih lanjut tentang faktor-faktor yang mempengaruhi kinerja pegawai. Karena dengan adanya motivasi yang baik akan menghasilkan kemauan bagi pegawai untuk bekerja lebih baik namun tanpa adanya pelatihan yang akan meningkatkan kemampuan yang baik pula pegawai tidak dapat bekerja dengan baik begitu juga 
sebaliknya, jika seorang pegawai memiliki kemampuan namun tidak ada kemauan dalam bekerja, maka hasil kerja yang dihasilkan juga tidak akan maksimal. Jadi adanya kemauan juga harus diiringi dengan adanya kemampuan sehingga akan menghasilkan kinerja pegawai yang baik bagi instansi tersebut. Berdasarkan latar belakang tersebut penulis tertarik untuk mengadakan penelitian di Dinas Pertanian Kabupaten Kediri dengan judul "Pengaruh Motivasi Dan Pelatihan Kerja Terhadap Kinerja pegawai PPL pada Dinas Pertanian Kabupaten Kediri.

\section{Rumusan Masalah}

Rumusan Masalah berdasarkan uraian pada latar belakang masalah, maka dapat ditarik rumusan masalah sebagai berikut:

1. Apakah Motivasi dan Pelatihan Kerja secara simultan berpengaruh terhadap Kinerja pegawai PPL pada Dinas Pertanian Kabupaten Kediri.

2. Apakah Motivasi berpengaruh terhadap Kinerja pegawai PPL pada Dinas Pertanian Kabupaten Kediri.

3. Apakah Pelatihan Kerja berpengaruh terhadap Kinerja pegawai PPL pada Dinas Pertanian Kabupaten Kediri.

\section{Tujuan Penelitian}

Tujuan umum penelitian ini adalah untuk mengidentifikasi pengaruh Motivasi Kerja dan Pelatihan Terhadap Pegawai PPL pada Dinas Pertanian Kabupaten Kediri. Sejumlah tujuan khusus yang melandasi dilaksanakannya penelitian ini dirumuskan sebagai berikut:

1. Menguji secara simultan pengaruh antara motivasi kerja dan pelatihan terhadap kinerja pegawai PPL pada Dinas Pertanian Kabupaten Kediri.

2. Menguji pengaruh Motivasi terhadap Kinerja pegawai PPL pada Dinas Pertanian Kabupaten Kediri.

3. Menguji pengaruh Pelatihan Kerja terhadap Kinerja pegawai PPL pada Dinas Pertanian Kabupaten Kediri.

\section{Manfaat Penelitian}

1. Manfaat Teoritis

Hasil Penelitian bisa digunakana sebagai literasi untuk peneliti selanjutnya.

\section{Pelatihan Kerja}

Pelatihan kerja adalah suatu upaya dalam rangka pengembangan sum ber daya
Dengan demikian akan memudahkan pencarian alternatif pemecahan masalahmasalah dalam penelitian tersebut.

2. Manfaat Empiris

Memberikan wawasan kepada masyarakat atau pembaca lainnya bahwa motivasi dan pelatihan sangat penting untuk diperhatikan dalam menilai sebuah kinerja disebuah Instansi.

\section{Motivasi}

Motivasi adalah dorongan yang timbul pada diri seseorang secara sadar atau tidak sadar untuk melakukan suatu tindakan dengan tujuan tertentu Kompri (2015:1). Menurut Samsudin (2009:81), motivasi adalah proses mempengaruhi atau mendorong dari luar terhadap seseorang atau kelompok pekerja agar mereka mau melaksanakan sesuatu yang telah ditetapkan. Pendapat lain dari Rivai dan Sagala (2009:837), motivasi adalah serangkaian sikap dan nilai-nilai yang mempengaruhi individu untuk mencapai hal yang spesifik sesuai dengan tujuan individu. Sejalan dengan Samsudin, Rivai dan Sagala, menurut Hasibuan (2010:141), motivasi adalah hal yang menyebabkan, menyalurkan, dan mendukung perilaku manusia supaya mau bekerja giat dan antusias mencapai hasil yang optimal. Menurut Behnaz (2013), Motivasi dapat didefinisikan sebagai proses psikologis yang dapat mendorong dan menstimulasi seseorang yang dapat mencapai daftar teratas dalam target penjualan atau menjadi anggota tim yang salah.

Menurut Suwanto (2011:177), bahwa "motivasi kerja pegawai dipengaruhi oleh kebutuhan fisik, kebutuhan akan keamanan, keselamatan, kebutuhan sosial, kebutuhan akan penghargaan diri dan kebutuhan perwujudan diri". Kemudian dari faktor tersebut diturunkan menjadi indikatorindikator untuk mengetahui tingkat motivasi kerja pada pegawai, yaitu:

1. Kebutuhan fisik

2. Kebutuhan rasa aman

3. Kebutuhan social

4. Kebutuhan harga diri

5. Kebutuhan aktualisasi diri

manusia, oleh karena itu pelatihan kerja merupakan bagian dari suatu proses pendidikan yang tujuannya adalah untuk 
meningkatkan kemampuan atau keterampilan tertentu pada seseorang atau kelompok orang. Ada berbagai macam pengertian pelatihan kerja dan batasannya dari para ahli dengan sudut pandang yang berbeda. Oemar Hamalik (2000: 10), menyatakan bahwa pelatihan adalah suatu proses yangmeliputi serangkaian tindakan (upaya) yang dilaksanakan dengan sengaja dalam bentuk pemberian bantuan kepada tenaga kerja yang dilakukan oleh tenaga professional kepelatihan dalam satuan waktu yang bertujuan untuk meningkatkan kemampuan kerja peserta dalam bidang pekerjaan tertentu guna meningkatkan efektivitas dan produktivitas dalam suatu organisasi. B. Siswanto Sastrohadiwiryo (2002: 199), menyatakan pelatihan merupakan proses membantu para tenaga kerja untuk memperoleh efektivitas dalam pekerjaan mereka yang sekarang atau yang akan datang melalui pengembangan kebiasaan tentang pikiran, tindakan, kecakapan, penge tahuan, dan sikap yang layak.

Indikator-indikator pelatihan menurut Anwar Prabu Mangkunegara (2012 : 116), diantaranya:

1. Jenis pelatihan

2. Tujuan pelatihan

3. Materi

4. Metode yang digunakan

5. Kualifikasi peserta

6. Kualifikasi pelatih

7. Waktu

\section{Kinerja}

Menurut Sutrisno (2010:151) kinerja adalah hasil kerja yang telah dicapai seseorang dari tingkah laku kerjanya dalam melaksanakan aktivitas kerja, sedangkan menurut Mangkunegara (2009:67), kinerja adalah hasil kerja secara kualitas dan kuantitas yang dicapai oleh seseorang pegawai dalam melaksanakan tugasnya sesuai dengan tanggungjawab yang diberikan kepadanya. Kinerja karyawan didefinisikan sebagai variabel yang memiliki banyak dimensi dan komponen serta elemen yang berbeda sesuai dengan pekerjaannya. Menurut Darsana (2013) kinerja pegawai terdiri dari beberapa indikator yaitu: 1) bekerja berdasarkan standar instansi, hasil kerja, target dan tepat waktu; 2) pekerjaan bisa diselesaikan; 3) kehadiran tinggi; 4) saling membantu dan saling menghormati antar karyawan; 5) peduli dengan keamanan kerja; 6) menyampaikan risiko kesalahan rekan kerja dan melakukan tugas yang diberikan, dan 7) menunjukkan kreativitas dengan ide-ide baru.

Menurut Bernadin (2010:25) "Berhasil tidaknya kinerja yang telah dicapai oleh organisasi dipengaruhi oleh tingkat kinerja pegawai secara individual maupun secara kelompok". Dengan asumsi semakin baik kinerja pegawai maka diharapkan hasil suatu kinerja organisasi semakin baik. Beberapa pendekatan untuk mengukur sejauh mana pegawai mencapai suatu kinerja secara individual adalah sebagai berikut:

1. Kualitas

2. Kuatitas

3. Ketepatan waktu

4. Efektifitas

5. Kemandirian

\section{Metodologi Penelitian \\ Rancangan Penelitian}

Penelitian menggunakan pendekatan kuantitatif yang menampilkan analisis dan bersifat statistik dengan angka dan bertujuan untuk menguji hipotesis yang telah ditetapkan (Sugiono, 2008). Dengan metode ini diharapkan dapat mengungkapkan pengaruh Motivasi dan Pelatihan Kerja terhadap Kinerja pegawai PPL pada Dinas Pertanian Kabupaten Kediri.

\section{Waktu Penelitian}

Penelitian ini dilaksanakan pada pegawai PPL Dinas Pertanian Kabupaten Kediri yang berlokasi dibeberapa kecamatan wilayah kabupaten kediri dan dilaksanakan pada tanggal 22 februari sampai 26 februari 2021.

Populasi dan Sampel

Menurut Sugiyono (2014:115), populasi penelitian adalah wilayah generalisasi yang terdiri atas objek atau subyek yang mempunyai kualitas dan karakteristik tertentu yang ditetapkan oleh peneliti untuk dipelajari dan kemudian ditarik kesimpulannya. Jumlah populasi pegawai PPL pada Dinas Pertanian Kabupaten Kediri Adalah 149 orang yang terdiri dari 84 pegawai PNS dan 65 orang Pegawai non PNS.

Menurut Sugiyono (2014:81), Sampel adalah bagian dari jumlah karakteristik yang 
dimiliki oleh populasi tersebut. Pengambilan sampel harus sesuai dengan kualitas dan karakteristik suatu populasi. Bila populasi besar, dan peneliti tidak mungkin mempelajari semua yang ada pada populasi, maka peneliti bisa menggunakan sampel.

\section{Teknik Pengumpulan Data \\ 1. Data Primer}

Data yang diperoleh secara langsung dari objek penelitian tentang motivasi dan pelatihan pada Dinas Pertanian Kabupaten Kediri yaitu melalui penyebaran kuesioner dan wawancara dengan pihak terkait.

\section{Data Sekunder}

Data sekunder merupakan data yang di peroleh bukan dari sumber secara langsung, melainkan melalui buku, jurnal, Thesis terdahulu atau yang sudah di kumpulkan oleh pihak lain atau sudah diolah. Dalam hal ini meliputi susunan struktur organisasi, sejarah singkat Dinas Pertanian Kabupaten Kediri dan lain- lain.

\section{Teknik Pengambilan Sampel}

Menurut Arikunto (2010 : 134-185) Sampel merupakan bagian dari jumlah dan karakteristik yang dimiliki oleh populasi tersebut. Teknik pengambilan sampel pada penelitian ini menggunakan metode Random sampling, karena populasi penelitian berjumlah lebih dari 100 maka maka peneliti menentukan jumlah sampel menggunakan rumus Slovin yaitu, $\mathrm{n}=\mathrm{N} /\left(1+\left(\mathrm{N} \mathrm{x} \mathrm{e}^{2}\right)\right)$. Hal ini dilakukan karena status pegawai PPL terbagi menjadi 2 yaitu, tenaga PNS dan PPPK. Maka dari itu peneliti mengambil kedua jenis status pegawai PPL secara acak supaya mengetahui pengaruh Motivasi dan Pelatihan kerja secara merata pada Dinas Pertanian Kabupaten Kediri yang digunakan sebagai populasi yaitu sebanyak 149 orang.

\section{Teknik Analisis Data \\ 1. Uji Statistik \\ Deskriptif}

Statistik deskriptif digunakan untuk memberikan gambaran variabel- variabel yang diteliti, mencakup nilai rata-rata (mean, nilai minimum, nilai maksimum, dan standar deviasi (Priyatno, 2016).

\section{Uji Asumsi Klasik}

Penggunaan model analisis regresi berganda terikat dengan sejumlah asumsi dan harus memenuhi asumsi-asumsi klasik yang mendasari model tersebut. Pengujian asumsi yang harus dipenuhi agar Persamaan regresi dapat digunakan dengan baik (uji persyaratan analisis) sebagai berikut :

a. Uji Normalitas

Menurut Duwi Priyatno dalam jurnal Tri Wartono (2018 : 85) uji normalitas pada model regresi ini digunakan untuk menguji apakah nilai residual yang dihasilkan dari regresi terdistribusi secara normal atau tidak. Kriteria pengambilan keputusan yaitu jika signifikan $>0,05$ maka data berdistribusi normal, dan jika signifikansi < 0,05 maka data tidak berdistribusi normal.

b. Uji Autokorelasi

Menurut Duwi Priyanto dalam jurnal Tri Wartono (2018:85) Autokorelasi adalah keadaan dimana pada model regresi ada korelasi antar residual pada periode $t$ dengan residual pada periode sebelumnya $(\mathrm{t}-1)$. Suatu model dapat dinyatakan tidak terjadi gejala autokorelasi jika nilai probabilitas nilai Durbin - Waston > 0,05 .

c. Uji Multikolinearitas

Menurut Duwi Priyanto dalam jurnal Tri Wartono (2018:85) Uji multikolinearitas bertujuan untuk menguji adaya korelasi antar variabel bebas (independen). Suatu model persamaan regresi dikatakan bebas dari gejala multikolinearitas, apabila nilai dari variance inflation factor (VIF) di bawah 10 dan nilai tolerance value-nya di atas 0,10 .

d. Uji Heteroskedastisitas

Menurut Duwi Priyanto dalam jurnal Tri Wartono (2018:05) uji heterokedastisitas digunakan untuk mengetahui ada atau tidaknya ketidaksamaan varian dari residual untuk semua pengamatan pada model regresi. Jika hasil probabilitasnya memiliki nilai signifikansi $>$ nilai alphanya $(0,05)$, maka model ini tidak mengalami heteroskedastisitas.

\section{Regresi Linear Berganda}

Analisis regresi linier berganda digunakan untuk mengukur kekuatan hubungan dua variabel atau lebih yang menunjukkan arah hubungan antar variabel independen dengan variabel dependen. Berikut model persamaan regresi yang digunakan dalam penelitian ini :

$\mathrm{Y}=\mathrm{a}+\mathrm{b} 1 \mathrm{X} 1+\mathrm{b} 2 \mathrm{X} 2++\mathrm{b} 3 \mathrm{X} 3$ 
4. Uji T

Statistik uji t digunakan untuk menunjukkan seberapa jauh pengaruh satu variabel independen secara individual dalam menerangkan variasi variabel dependen (Ghozali, 2016: 97). Dengan kriteria jika pvalue $<0,05$ maka Ho ditolak dan jika $\mathrm{p}$ value $>0,05$ maka H0 diterima.

5. Uji F

Uji F digunakan untuk menunjukkan apakah semua variabel ndependen yang dimasukkan dalam model memiliki pengaruh secara bersama-sama (simultan) terhadap variabel dependen (Ghozali, 2016:96). Apabila probabilitas signifikansi $>0.05$, maka Ho diterima dan Ha ditolak. Apabila probabilitas signifikansi $<0.05$, maka Ho ditolak dan Ha diterima.

6. $\mathrm{Uji}^{2}$

Koefisien determinasi (R2) pada intinya mengukur seberapa jauh kemampuan model dalam menerangkan variasi variabel dependen. Nilai koefisien determinasi adalah antara nol dan satu. Nilai (R2) yang kecil berarti kemampuan variabel-variabel independen dalam menjelaskan variasi variabel dependen sangat terbatas. Nilai yang mendekati satu berarti variabelvariabel independen memberikan hampir semua informasi yang dibutuhkan untuk memprediksi variasi variabel dependen (Ghozali, 2011: 97).

\section{Hasil Dan Pembahasan \\ Gambaran Uumum}

Arah kebijakan Dinas Pertanian Kabupaten Kediri adalah meningkatkan pembangunan pertanian tenaman pangan, hortikultura dan perkebunan dengan memadukan sub sistem sarana prasarana, produksi, distribusi dan pemasaran serta sub system pendukung (permodalan, teknologi, SDM) secara utuh dan terintegrasi dengan memperhatikan keunggulan potensi ekosistem dan pariwisata.

\section{Hasil Analisis}

\section{Uji Validitas}

Uji validitas dilakukan untuk mengetahui apakah alat ukur yang telah disusun benarbenar mampu mengukur apa yang harus diukur.

\begin{tabular}{|c|c|c|c|}
\hline \multicolumn{4}{|c|}{ TABEL 4.8 HASIL UJI VALIDITAS } \\
\hline $\begin{array}{c}\text { NO } \\
\text { ITEM }\end{array}$ & R HTUNG & $\mathrm{R}_{\text {TABEI }}$ & KET. \\
\hline \multicolumn{4}{|c|}{ MOTIVASI } \\
\hline $\mathrm{X} 1.1$ & 0.601 & 0.000 & Valid \\
\hline $\mathrm{X} 1.2$ & 0.582 & 0.000 & Valid \\
\hline $\mathrm{X} 1.3$ & 0.848 & 0.000 & Valid \\
\hline $\mathrm{X} 1.4$ & 0,901 & 0,000 & Valid \\
\hline $\mathrm{X} 1.5$ & 0,709 & 0,000 & Valid \\
\hline \multicolumn{4}{|c|}{ PELATIHAN KERJA } \\
\hline $\mathrm{X} 2.1$ & 0.565 & 0.001 & Valid \\
\hline X2.2 & 0,483 & 0,005 & Valid \\
\hline $\mathrm{X} 2.3$ & 0,765 & 0.000 & Valid \\
\hline $\mathrm{X} 2.4$ & 0.799 & 0.000 & Valid \\
\hline $\mathrm{X} 2.5$ & 0.754 & 0.000 & Valid \\
\hline $\mathrm{X} 2.6$ & 0,749 & 0,000 & Valid \\
\hline $\mathrm{X} 2.7$ & 0.754 & 0.000 & Valid \\
\hline \multicolumn{4}{|c|}{ KINERJA } \\
\hline $\mathrm{X} 1.1$ & 0,508 & 0,003 & Valid \\
\hline $\mathrm{X} 1.2$ & 0,372 & 0.036 & Valid \\
\hline $\mathrm{X} 1.3$ & 0.708 & 0.000 & Valid \\
\hline $\mathrm{X} 1.4$ & 0.718 & 0.000 & Valid \\
\hline $\mathrm{X} 1.5$ & 0.768 & 0.000 & Valid \\
\hline
\end{tabular}

\section{Uji Reliabiltas}

Uji reliabilitas adalah untuk menguji seberapa akurat angket terhadap kesesuaian data yang diteliti sebagai hal yang dipertanggung jawabkan. Pengujian reliabilitas dalam penelitian ini menggunakan komputer dengan bantuan SPSS versi 16.0. jika nilai alpha $<0,06$ makatidak reliabel, dan nilai alpha $>0,06$ maka reliabel. Secara umum keandalan dalam kisaran $>0,060 \mathrm{~s} / \mathrm{d}$ 0,08 baik, serta dalam kisaran. 0,80 s/d 1.00 dianggap sangat baik.

Hasil Uji Reliabilitas Pengaruh Motivasi (XI) dan Pelatihan

\begin{tabular}{l} 
Kerja (X2) terhadap Kinerja Pegawai (Y) \\
\begin{tabular}{|c|c|c|c|}
\hline Variabel & Tolerance & Cronbach's Alpha & Keterangan \\
\hline Motivasi & 0,60 & 0,787 & Reliabel \\
\hline Pelatihan Kerja & 0,60 & 0,822 & Reliabel \\
\hline Kinerja & 0,60 & 0,619 & Reliabel \\
\hline
\end{tabular} \\
Sumber : SPSS \\
\hline
\end{tabular}

Berdasarkan tabel diatas semua variabel menunjukkan Cronbach Alpha lebih besar dari 0,60. Dengan demikian dapat ditarik kesimpulan bahwa semua variabel tersebut reliabel.

\section{Uji Asumsi Klasik}

\section{a. Uji Normalitas}

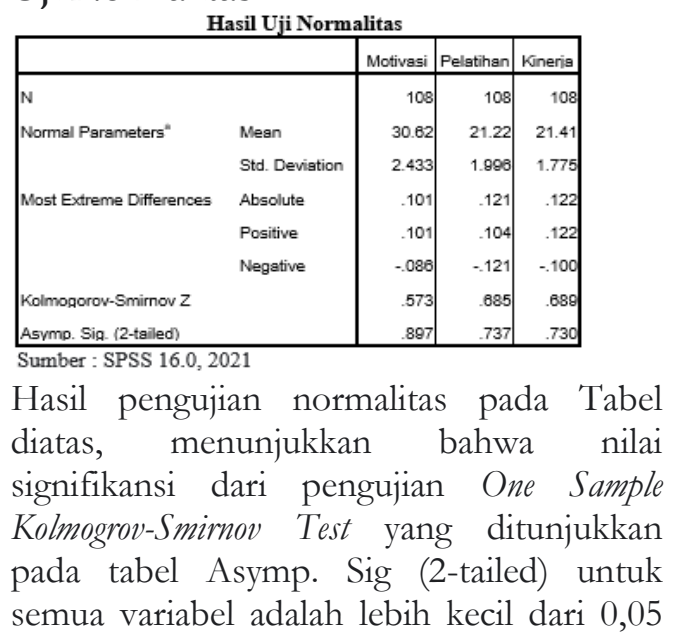


sehingga dapat disimpulkan bahwa seluruh variabel dalam penelitian ini terdistribusi secara tidak normal.

b. Uji MultiKolinearitas

\begin{tabular}{|c|c|c|c|c|c|c|c|}
\hline \multirow[b]{2}{*}{ Model } & \multicolumn{2}{|c|}{$\begin{array}{c}\text { Unstandardized } \\
\text { Coefficients }\end{array}$} & \multirow{2}{*}{\begin{tabular}{|c|}
$\begin{array}{c}\text { Standar } \\
\text { dized } \\
\text { Coeffici } \\
\text { ents }\end{array}$ \\
Beta \\
\end{tabular}} & \multirow[b]{2}{*}{$t$} & \multirow[b]{2}{*}{ Sig. } & \multicolumn{2}{|c|}{$\begin{array}{c}\text { Collinearity } \\
\text { Statistics } \\
\end{array}$} \\
\hline & B & $\begin{array}{l}\text { Std. } \\
\text { Error }\end{array}$ & & & & \begin{tabular}{|c|} 
Tolera \\
nce
\end{tabular} & VIF \\
\hline 1 (Constant) & 2.590 & 1.096 & & 2.362 & .025 & & \\
\hline Motivasi & .120 & .062 & .192 & 1.949 & .061 & .312 & 3.204 \\
\hline $\begin{array}{l}\text { Pelatihan } \\
\text { Keria }\end{array}$ & .709 & .088 & .790 & 8.021 & .000 & .312 & 3.204 \\
\hline
\end{tabular}

Berdasarkan Tabel diatas, hasil perhitungan nilai Variance Infation Foctor (VIF) dari senua variabel menunjukkan nilai dibawah 4 . sesuai dengan kriteria jika nilai VIF dibawah 4 maka dapat disimpulkan bahwa tidak ada multikolinearitas antar variabel motivasi dan pelatihan kerja dalam model regresi.

c. Uji Heteroskedastisitas

Hasil Uji Heteroskedastisitas

\begin{tabular}{|l|c|c|c|}
\hline \multirow{2}{*}{ Variabel } & \multicolumn{2}{|c|}{ Nilai } & \multirow{2}{*}{ Kesimpulan } \\
\cline { 2 - 3 } & F & Sig & \\
\hline $\begin{array}{l}\text { Motivasi dan } \\
\text { Pelatihan Kerja }\end{array}$ & 150,713 & 0,000 & Bebas Heteroskedastisitas \\
\hline
\end{tabular}

Bedasarkan Tabel diatas, menunjukkan nilai F yang ditemukan sebesar 150,713 dengan signifikan 0,000. Karena nilai signifikan kurang dari 0,05 maka dapat disimpulkan terjadi heteroskesdastisitas.

d. Uji Autokorelasi

Uji autokorelasi bertujuan menguji apakah dalam model regresi linear ada korelasi antara kesalahan pengganggu pada periode $t$ dengan kesalahan pengganggu pada periode t-1 (sebelumnya).

\begin{tabular}{|c|c|c|c|c|c|}
\hline Model & R & R Square & $\begin{array}{c}\text { Adjusted } \\
\text { R Square }\end{array}$ & $\begin{array}{c}\text { Std. Error } \\
\text { of the } \\
\text { Estimate }\end{array}$ & $\begin{array}{l}\text { Durbin } \\
\text { Watson }\end{array}$ \\
\hline 1 & 0,955 & 0,912 & 0,906 & 0,48586 & 1,943 \\
\hline
\end{tabular}

Berdasarkan tabel diatas diperoleh nilai Durbin-Watson sebesar 1,943 karena nilai terebut berada tidak antara 2 dan 4 maka dapat disimpulkan bahwa terjadi autokorelasi untuk persamaan regresi variabel kinerja pegawai atas variabel Motivasi dan Pelatihan Kerja.

\section{Uji Regresi Linier Berganda}



1. $\mathrm{R}=0,955$ artinya koefisien korelasi sebesar 0,955. Angka menunjukkan derajat korelasi antara variabel motivasi dan pelatihan kerja terhadap kinerja pegawai.

2. $\mathrm{R}$ square $=0,912$ artinya variansi dalam kinerja pegawai dapat dijelaskan oleh motivasi dan pelatihan kerja melalui model sebesar $91,2 \%$ sisanya $8,8 \%$ berasal dari variabel lain, atau dengan bahasa sederhana besarnya kontribusi motivasi dan pelatihan kerja terhadap kinerja pegawai adalah sebesar $91,2 \%$ dan sisanya $8,8 \%$ berasal dari variabel lain.

3. $\mathrm{B} \mathrm{X} 1=0,120$ artinya variansi dalam kinerja dapat dijelaskan oleh motivasi melalui model sebesar $12 \%$ sisanya $88 \%$ berasal dari variabel lain, atau dengan bahasa sederhana besarnya kontribusi motivasi terhadap kinerja pegawai adalah sebear $12 \%$ dan sisanya $88 \%$ berasal dari variabel lain.

4. $\mathrm{B} X 2=0,709$ artinya variansi dalam kinerja dapat dijelaskan oleh pelatihan kerja melalui model sebesar 91,2\% sisanya $8,8 \%$ berasal dari variabel lain, atau dengan bahasa sederhana besarnya kontribusi motivasi terhadap kinerja pegawai adalah sebear $91,8 \%$ dan sisanya $8,8 \%$ berasal dari variabel lain.

5. Adjusted $\mathrm{R}$ Square $=0,906$. Ukuran ini maknanya hampir sama dengan R Square, hanya saja Adjusted R Square ini nilainya lebih stabil karena sudah disesuaikan dengan jumlah variabel bebasnya.

6. Pada variable motivasi (X1) nilai $\mathrm{b}=$ 0,120 dan t hitung $1,949>2,045$ dengan sig $=0,061$. Oleh karena nilai sig. $<0,05$ maka H0 ditolak dan $\mathrm{H} 1$ diterima yang artinya motivasi berpengaruh secara parsial terhadap kinerja pegawai PPL 
pada Dinas Pertanian Kabupaten Kediri.

7. Pada variabel pelatihan kerja (X2) nilai b $=0,709$ dan $\mathrm{t}$ hitung $8,021<2,045$ dengan sig $=0,000$. Oleh karena nilai sig. $<0,05$ maka H0 diterima dan H1 ditolak yang artinya pelatihan kerja tidak berpengaruh secara parsial terhadap kinerja pegawai PPL pada Dinas Pertanian Kabupaten Kediri.

8. Hasil determinasi ditemukan $\mathrm{F}$ hitung sebesar 150,713 dengan sig. $=0,000$ dan F hitung $>$ F tabel 3,32. Oleh karena itu, nilai sig $<0,05$ maka $\mathrm{H} 0$ ditolak yang artinya motivasi dan pelatihan kerja berpengaruh secara simultan terhadap kinerja pegawai PPL pada Dinas Pertanian Kabupaten Kediri.

9. Berdasarkan hasil perhitungan yang tersaji pada tabel diatas, hasil Uji Regresi Linear Berganda dapat diperoleh persamaan regresi sebagai berikut :

$\mathrm{Y}=\mathrm{a}+\mathrm{b}_{1} \mathrm{X}_{1}+\mathrm{b}_{2} \mathrm{X}_{2}$

$\mathrm{Y}=2,590+0,120+0,709$

\section{Kesimpulan}

1. Berdasarkan hasil penelitian, variabel Motivasi dan Pelatihan Kerja secara simultan berpengaruh terhadap Kinerja Pegawai PPL. Hal ini dibuktikan berdasarkan hasil perhitungan SPSS 16.0 yang menyatakan bahwa $\mathrm{F}_{\text {hitung }} 150,713>$ $F_{\text {tabel }}$ yaitu 3,32 dengan Sig. 0,000 $<0,05$

2. Berdasarkan hasil penelitian, variabel Motivasi secara parsial berpengaruh terhadap Kinerja Pegawai PPL. Hal ini dibuktikan berdasarkan hasil perhitungan SPSS 16.0 yang menyatakan bahwa nilai $\mathrm{b} 1=0,120$ dengan $\mathrm{t}=1,949$ dan sig. $=$ 0,061. Oleh karena nilai sig. $<0,05$ maka $\mathrm{H} 0$ diterima dan $\mathrm{H} 1$ ditolak yang artinya variabel motivasi tidak berpengaruh terhadap kinerja pegawai PPL pada Dinas Pertanian Kabupaten Kediri.

3. Berdasarkan hasil penelitian, variabel Pelatihan Kerja secara parsial berpengaruh terhadap Kinerja Pegawai PPL. Hal ini dibuktikan berdasarkan hasil perhitungan SPSS 16.0 yang menyatakan bahwa nilai $\mathrm{b} 1=0,709$ dengan $\mathrm{t}=8,021$ dan sig. $=0,000$. Oleh karena nilai sig. $<$ 0,05 maka H0 ditolak dan H1 diterima yang artinya variabel pelatihan kerja berpengaruh terhadap kinerja pegawai
PPL pada Dinas Pertanian Kabupaten Kediri.

\section{Saran}

1. Peneliti menyarankan kepada peneliti selanjutya untuk meneliti variabel lain selain motivasi, karena pada variabel motivasi tidak terdapat pengaruh yang sihnifikan terhadap kinerja pegawai PPL yang berstatus PNS maupun PPPK.

2. Penyuluhan Pertanian Lapangan (PPL) dapat menumubuh kembangkan kelompok tani dengan cara memperkuat ikatan antar sesama petani dalam kelompoknya untuk mewujudkan kelompok tani yang berkelanjutan.

3. Penyuluh Pertanian Lapangan (PPL) yang berstatus PPPK diharapkan dapat melaksanakan tugas secara optimal meskipun berbeda dalam aspek tunjangan dengan pegawai yang berstatus PNS dan melaksanakan tugas sesuai apa yang diharapkan demi tercapainya visi dan misi pada Dinas Pertanian Kabupaten Kediri.

\section{Daftar Pustaka}

A.A Anwar Prabu Mangkunegara. 2012. Evaluasi Kinerja Sumber Daya Manusia. Bandung: PT. Refika Aditama.

Andarini, P. dan Januarti, I. 2010. Hubungan Karakteristik Dewan Komisaris dan Perusahaan Terhadap Keberadaan Komite Manajemen Risiko Pada Perusahaan Go Public Indonesia. Jurnal Akuntansi dan Keuangan Indonesia, Vol. 9 No. 1.

Annisa, N.A. 2011. Pengaruh Corporate Governance terhadap Tax Avoidance. Jurnal Akuntansi dan Auditing . Surakarta: Fakultas Ekonomi dan Bisnis, Universitas Sebelas Maret. Vol. 7, No. 2, hal 68-94.

Annisa, N.A. dan Kurniasih, L. 2012. Pengaruh Corporate Governance Terhadap Tax Avoidance. Jurnal Akuntansi dan Auditing, Universitas Sebelas Maret. Solo. Vol. 8, No. 2, Hal: 95-189.

Ardiansyah, D. dan Zulaikha. 2014. Pengaruh Size, Leverage, Profitabilitas, Capital Intensity Ratio dan Komisaris Independen terhadapa Effective Tax Rate (ETR). Diponegoro Journal of Accounting. 
Vol. 3 No. 2 Hal 1-9.

Arikunto Suharsimi, (2010), Prosedur Penelitian Suatu Pendekatan Praktik, Rineka Cipta, Jakarta.

Basri, W. Teguh M. dan Rusli, Y.M. 2015. Pengaruh Return on Asset, Leverage, Ukuran Perusahaan, Kompensasi Rugi Fiskal dan Kepemilikan Institusi Terhadap Penghindaran Pajak. Simposium Nasional Akuntansi XVIII.Medan.

Bernardin, H.John and Russel. 2010. Human Resource Management. New York: McGraw-Hill.

Budiman, J. dan Setiyono. 2012. Pengaruh Karakteristik Eksekutif Terhadap Penghindaran Pajak (Tax Avidance). Artikel. Uiversitas Islam Sultan Agung. Semarang.

Butje, S. dan Tjondro, E. 2014. Pengaruh Karakteristik Eksekutif dan Koneksi Politik Terhadap Tax Avoidance. Tax Accounting Review, Vol. 4, No. 2, Hal: 1-9. Universitas Kristen Petra.

Chai, H. dan Liu, Q. 2010. Competition and Corporate Tax Avoidance: Evidence From Chinese Industrial Firms. www.ssrn.com.

Damayanti, F. dan Susanto, T. 2015. Pengaruh Komite Audit, Kualitas Audit, Kepemilikan Institusional, Risiko Perusahaan dan Return On Assets Terhadap Tax Avoidance. Jurnal Bisnis dan Manajemen, UIN syarif Hidayatullah. Jakarta. Vol. 5, No. 2, Hal:187-206.

Darmawan, I.G.H. dan Sukartha, I.M. 2014. Pengaruh Penerapan Corporate Governance, Leverage, Return on Assets dan Ukuran Perusahaan Pada Penghindaran Pajak. E-jurnal Akuntansi, Universitas Udayana. Bali. Vol. 9, No. 1, Hal: 143-161, ISSN 2302-8556.

Danang, Sunyoto. 2012. Manajemen Sumber Daya Manusia. Jakarta: PT Buku Seru. http://repository.upi.edu/17628/4/S MBS 1001311 Bibliography.
Diantari, P.R. dan Ulupui, I.G.K.A. 2016. Pengaruh Komite Audit, Proporsi Independen, dan Proporsi Kepemilikan Institusional Terhadap Tax Avoidance. E-Jurnal Akuntansi Unversitas Udayana, Bali. Vol. 16, No.1, Hal: 702-732. ISSN: 2302-8556.

Fadhilah, R. 2014. Pengaruh Good Corporate Governance Terhadap Tax Avoidance (Studi Empiris Pada Perusahaan Manufaktur yang Terdaftar di BEI 2009-2011). Artikel. Universitas Negeri Padang.

Faizah, S.N. dan Adhivinna, V.V. 2017. Pengaruh Return On Asset, Leverage, Kepemilikan Institusional dan Ukuran Perusahaan Terhadap Tax Avoidance. Jurnal Akuntansi, Universitas PGRI Yogyakarta. Vol. 5, No. 2, Hal: 136145, p-ISSN: 2088-768X, e-ISSN: 2540-9646.

Ghozali, I. 2011. Aplikasi Analisis Multivariate dengan Program IBM SPSS, Edisi Kelima Cetakan Kelima. Badan Penerbit Universitas Diponegoro.

Ghozali, Imam. 2016. Aplikasi Analisis Multivariete Dengan Program IBM SPSS 23 (Edisi 8). Cetakan ke VIII. Semarang : Badan Penerbit Universitas Diponegoro.

Hamalik, Oemar. (2015). Kurikulum dan Pembelajaran. Jakarta: Bumi Aksara.

Hasibuan, M (2012). Manajemen Sumber Daya Manusia dan Kunci Keberhasilan. Jakarta: Haji Mas Agung.

Suwatno dan Donni Juni Priansa. 2011. Manajemen Sumber Daya Manusia Dalam Organisasi Publik Dan Bisnis. Bandung : Cv. Alfabeta.

Sutrisno, Edy. 2010. Manajemen Sumber Daya Manusia. Jakarta: Kencana Prenada Media Group.

Wibowo (2012). Manajemen Kinerja. Jakarta: raja Grafindo Persada. 